\title{
Fault Movement Potential of Marzanabad Area, North Alborz, Iran
}

\author{
Hamid Moghimi1, Mehran Arian ${ }^{*}$, Ali Sorbi2 \\ ${ }^{1}$ Department of Geology, Science and Research Branch, Islamic Azad University, Tehran, Iran \\ ${ }^{2}$ Department of Geology, Karaj Branch, Islamic Azad University, Karaj, Iran \\ Email: ${ }^{*}$ mehranarian@yahoo.com
}

Received 13 February 2015; accepted 9 March 2015; published 16 March 2015

Copyright (C) 2015 by authors and Scientific Research Publishing Inc.

This work is licensed under the Creative Commons Attribution International License (CC BY). http://creativecommons.org/licenses/by/4.0/

(c) (i) Open Access

\begin{abstract}
The major Quaternary faults of Marzanabad in the north Alborz can be classified based on their strikes into two sets: northwest and eastwest. In this paper, we use a model to evaluate their movement potential. Their theoretical model is based on the relationship between fault geometrical characteristics and regional tectonic stress field. The results show that Taleqan, Kandovan Chitan-Dozbon and Makaroud-Dalir fault zones are of the highest movement potential in the area. Also, the region where the fault zones have been intersected (northeastern part of study area) is prone to high seismicity; however, these fault zones don't have high movement potentials.
\end{abstract}

\section{Keywords}

Marzanabad, Faults, Alborz, Movement, Potential, Iran

\section{Introduction}

Seismicity is closely related to active Quaternary faults. This attracts many researchers to investigate the quantitative relationships between them. As a new parameter, FMP is defined to quantify earthquake risk along active faults by [1]. Therefore, we use it for evaluation of earthquake risk Marzanabad in the north Alborz, Iran. The landforms in this area are mainly controlled by two sets of Quaternary faults, striking northwest and eastwest, respectively (Figure 1).

The questions to be addressed in this paper are: 1) what are the activity levels of these faults? And 2) will these faults cause destructive earthquakes? Previous work regarding these topics was mainly based on field works [2]. In this paper, we use a new method to evaluate fault activity by considering the mechanical relationships between fault geometry and regional tectonic stress field. This method has been used to evaluate the fault

${ }^{*}$ Corresponding author. 


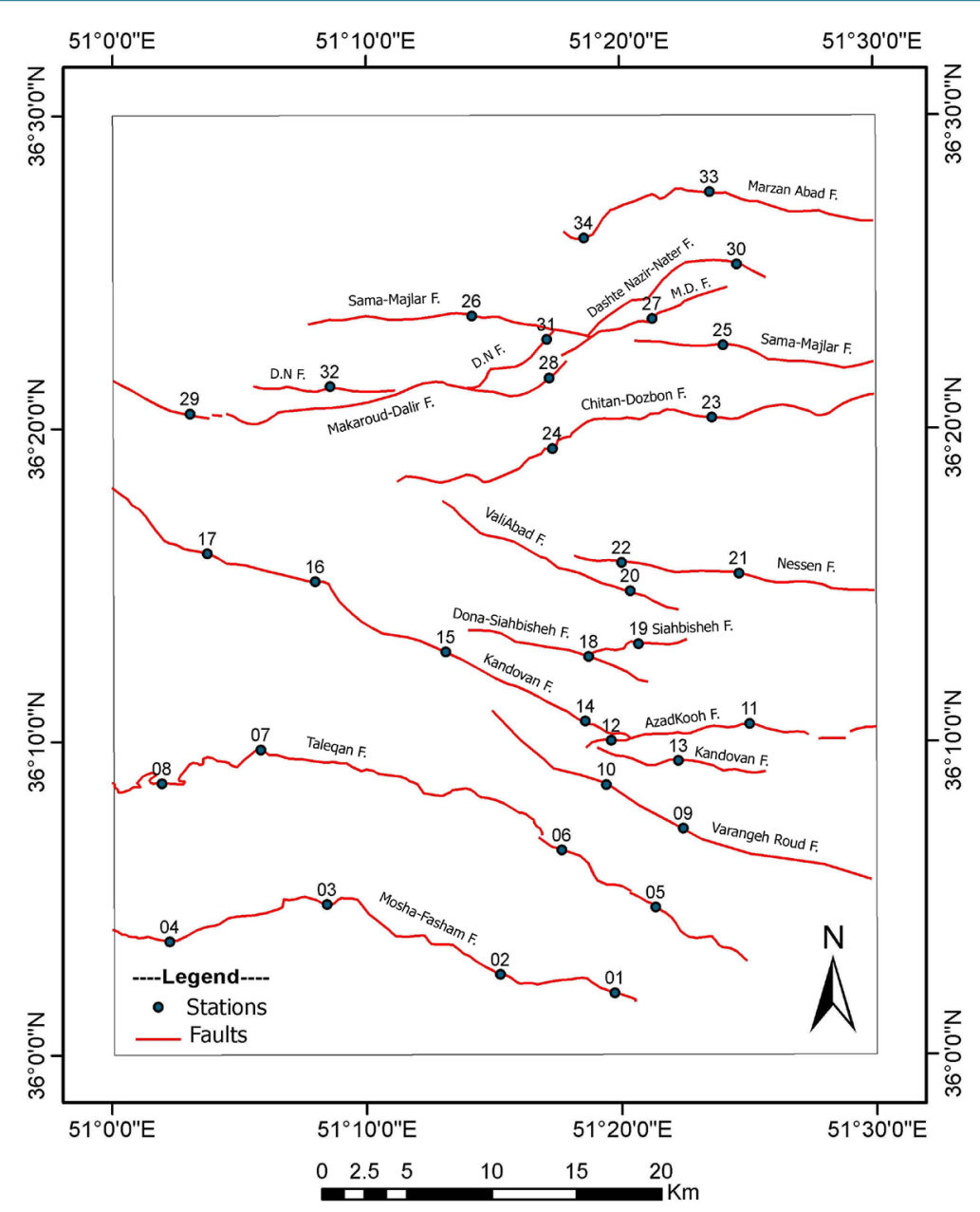

Figure 1. Stations of fault attitude measurements on Marzanabad area.

movement potentials of all the major Quaternary faults Marzanabad in the north Alborz.

\section{Materials and Methods}

\subsection{Fault Sets}

Quaternary faults are well developed in Marzanabad area. They were classified into two sets based on their strikes: northwest and east -west. The northwest striking fault set comprises Mosha-Fasham, Taleqan, Varangeh Roud, Kandovan, Dona-Siahbisheh and Valiabad fault zones in the southern part of study area (Figure 1).

The east-west striking fault set are well exposed and can be traced intermittently for a long distance in nearly east-west direction. In this set, there are Nessen, Chitan-Dozbon, Sama-Majlar, Makaroud-Dalir, Dashte NazirNater, Marzanabad, Azadkooh, Siahbishehfault zone in the northern part of study area (Figure 1).

In summary, all of these fault zones are active in current tectonic regime (CTR) and characterized by seismic events (Table 1). These events have shown that, seismic layer is in 20 - $30 \mathrm{~km}$ depth. This area has low to moderate earthquakes with intermediate frequency and repeat time.

In the following sections, we will evaluate the earthquake risk along these faults, and discuss which fault is most favored to move under the influence of present-day tectonic stress field. We make this evaluation based on the relationships between tectonic stress orientation and fault geometric properties.

\subsection{Theoretical Model for Analysis of Fault Movement Potential}

The fault movement potential (FMP) is closely related to tectonic stress ( $\sigma$ ), fault plane geometry (G) and the 
Table 1. Seismic events of study area (1957-2015).

\begin{tabular}{|c|c|c|c|c|c|c|c|}
\hline No. & Date (yyyy/mm/dd) & Time (UTC) & Latitude & Longitude & Depth & Magnitude & Reference \\
\hline 1 & $1957 / 05 / 06$ & $15: 06: 51.0$ & 36.40 & 51.50 & & Ms:4.8 & MEA \\
\hline 2 & $1959 / 05 / 01$ & 08:24:02.0 & 36.38 & 51.16 & 33 & M:5.3 & NOW \\
\hline 3 & 1970/10/03 & 06:57:03.0 & 36.01 & 51.31 & 78 & mb:4.1 & ISC \\
\hline 4 & $1981 / 08 / 04$ & $18: 53: 59.0$ & 36.45 & 51.27 & & mb:4.7 & ISC \\
\hline 5 & 1998/12/03 & 21:07:18.0 & 36.30 & 51.11 & 100 & mb:3.9 & ISC \\
\hline 6 & $2004 / 05 / 28$ & $14: 47: 51.0$ & 36.49 & 51.37 & 10 & ML:2.8 & IIEES \\
\hline 7 & $2004 / 05 / 28$ & $16: 45: 21.0$ & 36.26 & 51.46 & 28 & ML:2.8 & IIEES \\
\hline 8 & $2004 / 05 / 28$ & $17: 34: 51.0$ & 36.48 & 51.36 & 22 & ML:3.3 & IIEES \\
\hline 9 & $2004 / 05 / 28$ & $17: 51: 21.0$ & 36.27 & 51.38 & 15 & ML:3.2 & IIEES \\
\hline 10 & $2004 / 05 / 28$ & $19: 47: 05.0$ & 36.43 & 51.40 & 25 & $\mathrm{mb}: 4.5$ & EHB \\
\hline 11 & $2004 / 05 / 28$ & 20:07:26.0 & 36.40 & 51.38 & 28 & ML:3.2 & IIEES \\
\hline 12 & $2004 / 05 / 28$ & 20:09:18.0 & 36.41 & 51.37 & 28 & ML:3.1 & IIEES \\
\hline 13 & $2004 / 05 / 28$ & $20: 25: 31.0$ & 36.17 & 51.47 & 28 & ML:3.4 & IIEES \\
\hline 14 & $2004 / 05 / 28$ & $20: 31: 20.0$ & 36.41 & 51.40 & 28 & ML:3.2 & IIEES \\
\hline 15 & $2004 / 05 / 28$ & 20:32:57.0 & 36.46 & 51.42 & 28 & ML:3.3 & IIEES \\
\hline 16 & $2004 / 05 / 28$ & $20: 49: 25.0$ & 36.45 & 51.37 & 28 & ML:2.8 & IIEES \\
\hline 17 & $2004 / 05 / 28$ & 21:03:35.0 & 36.32 & 51.43 & 28 & ML:3.5 & IIEES \\
\hline 18 & $2004 / 05 / 28$ & $21: 22: 48.0$ & 36.37 & 51.42 & 28 & ML:2.5 & IIEES \\
\hline 19 & $2004 / 05 / 28$ & $22: 32: 34.0$ & 36.36 & 51.38 & 28 & ML:2.6 & IIEES \\
\hline 20 & $2004 / 05 / 28$ & $23: 07: 27.0$ & 36.39 & 51.40 & 28 & ML:2.6 & IIEES \\
\hline 21 & $2004 / 05 / 29$ & $00: 25: 48.0$ & 36.36 & 51.43 & 28 & ML:3.4 & IIEES \\
\hline 22 & $2004 / 05 / 29$ & 01:57:58.0 & 36.36 & 51.37 & 28 & ML:2.9 & IIEES \\
\hline 23 & $2004 / 05 / 29$ & 03:54:27.0 & 36.47 & 51.40 & 28 & ML:3.3 & IIEES \\
\hline 24 & $2004 / 05 / 29$ & 04:53:04.0 & 36.37 & 51.42 & 28 & ML:3.7 & IIEES \\
\hline 25 & $2004 / 05 / 29$ & 05:34:50.0 & 36.44 & 51.43 & 28 & ML:2.8 & IIEES \\
\hline 26 & $2004 / 05 / 29$ & 06:14:20.0 & 36.47 & 51.41 & 28 & ML:3.4 & IIEES \\
\hline 27 & $2004 / 05 / 29$ & 06:34:14.0 & 36.43 & 51.43 & 28 & ML:3.2 & IIEES \\
\hline 28 & $2004 / 05 / 29$ & 09:23:49.0 & 36.49 & 51.40 & 14 & $\mathrm{mb}: 4.7$ & EHB \\
\hline 29 & $2004 / 05 / 29$ & $10: 20: 40.0$ & 36.37 & 51.41 & 28 & ML:3.6 & IIEES \\
\hline 30 & $2004 / 05 / 29$ & 11:01:32.0 & 36.42 & 51.38 & 28 & ML:4.2 & IIEES \\
\hline 31 & $2004 / 05 / 29$ & $12: 56: 43.0$ & 36.50 & 51.42 & 28 & ML:3.6 & IIEES \\
\hline 32 & $2004 / 05 / 29$ & $13: 34: 24.0$ & 36.39 & 51.39 & 28 & ML:3.3 & IIEES \\
\hline 33 & $2004 / 05 / 29$ & $14: 56: 46.0$ & 36.45 & 51.44 & 28 & ML:3.7 & IIEES \\
\hline 34 & $2004 / 05 / 29$ & $15: 03: 49.0$ & 36.50 & 51.41 & 28 & ML:3.2 & IIEES \\
\hline 35 & $2004 / 05 / 29$ & $15: 23: 49.0$ & 36.50 & 51.35 & 28 & ML:3.3 & IIEES \\
\hline 36 & $2004 / 05 / 29$ & $15: 41: 03.0$ & 36.46 & 51.42 & 28 & ML:3.9 & IIEES \\
\hline 37 & $2004 / 05 / 29$ & $17: 30: 26.0$ & 36.49 & 51.44 & 28 & ML:3.9 & IIEES \\
\hline 38 & $2004 / 05 / 29$ & 18:38:07.0 & 36.45 & 51.37 & 28 & ML:4.6 & IIEES \\
\hline 39 & $2004 / 05 / 29$ & $18: 42: 45.0$ & 36.43 & 51.41 & 28 & ML:3.8 & IIEES \\
\hline 40 & $2004 / 05 / 29$ & 19:58:19.0 & 36.46 & 51.45 & 28 & ML:3.5 & IIEES \\
\hline 41 & $2004 / 05 / 29$ & $22: 55: 19.0$ & 36.43 & 51.36 & 28 & ML:3.9 & IIEES \\
\hline 42 & $2004 / 05 / 29$ & $23: 05: 46.0$ & 36.48 & 51.36 & 28 & ML:2.6 & IIEES \\
\hline
\end{tabular}


H. Moghimi et al.

\section{Continued}

\begin{tabular}{|c|c|c|c|c|c|c|c|}
\hline 43 & $2004 / 05 / 30$ & 02:41:27.0 & 36.46 & 51.45 & 28 & ML:3.6 & IIEES \\
\hline 44 & $2004 / 05 / 30$ & 07:48:53.0 & 36.46 & 51.38 & 28 & ML:3.5 & IIEES \\
\hline 45 & $2004 / 05 / 30$ & 08:57:06.0 & 36.18 & 51.49 & 28 & ML:2.9 & IIEES \\
\hline 46 & $2004 / 05 / 30$ & $11: 49: 02.0$ & 36.36 & 51.36 & 28 & ML:2.8 & IIEES \\
\hline 47 & $2004 / 05 / 30$ & 13:09:55.0 & 36.41 & 51.45 & 28 & ML:4 & IIEES \\
\hline 48 & $2004 / 05 / 30$ & $15: 48: 46.0$ & 36.44 & 51.46 & 28 & ML:3.5 & IIEES \\
\hline 49 & $2004 / 05 / 30$ & $16: 18: 24.0$ & 36.26 & 51.44 & 28 & ML:3.2 & IIEES \\
\hline 50 & $2004 / 05 / 30$ & 18:03:19.0 & 36.44 & 51.45 & 28 & ML:2.7 & IIEES \\
\hline 51 & $2004 / 05 / 31$ & 08:12:16.0 & 36.46 & 51.26 & 14 & ML:3.7 & IIEES \\
\hline 52 & $2004 / 06 / 01$ & $00: 35: 32.0$ & 36.45 & 51.49 & 28 & ML:3.2 & IIEES \\
\hline 53 & $2004 / 06 / 01$ & 02:41:28.0 & 36.37 & 51.46 & 28 & ML:3.3 & IIEES \\
\hline 54 & $2004 / 06 / 01$ & $06: 22: 01.0$ & 36.39 & 51.45 & 28 & ML:2.6 & IIEES \\
\hline 55 & $2004 / 06 / 01$ & $10: 57: 46.0$ & 36.45 & 51.41 & 28 & ML:2.7 & IIEES \\
\hline 56 & $2004 / 06 / 02$ & $11: 12: 25.0$ & 36.50 & 51.41 & 28 & ML:3 & IIEES \\
\hline 57 & $2004 / 06 / 05$ & $00: 10: 45.0$ & 36.40 & 51.40 & 28 & ML:2.8 & IIEES \\
\hline 58 & $2004 / 06 / 05$ & 20:58:14.0 & 36.42 & 51.43 & 28 & ML:3.2 & IIEES \\
\hline 59 & $2004 / 06 / 06$ & $06: 08: 21.0$ & 36.44 & 51.41 & 28 & ML:2.8 & IIEES \\
\hline 60 & $2004 / 06 / 08$ & $04: 34: 36.0$ & 36.47 & 51.38 & 28 & ML:2.5 & IIEES \\
\hline 61 & $2004 / 06 / 24$ & 02:36:28.0 & 36.47 & 51.42 & 28 & ML:2.8 & IIEES \\
\hline 62 & $2004 / 06 / 27$ & 04:51:35.0 & 36.49 & 51.40 & 12 & ML:3.3 & IIEES \\
\hline 63 & $2004 / 07 / 11$ & 13:16:46.7 & 36.35 & 51.31 & 14 & ML:3.3 & IIEES \\
\hline 64 & $2004 / 07 / 18$ & 13:44:18.9 & 36.43 & 51.42 & 31 & ML:2.5 & IIEES \\
\hline 65 & 2006/03/07 & 19:58:42.7 & 36.30 & 51.41 & 33 & ML:2.9 & IIEES \\
\hline 66 & $2006 / 03 / 08$ & 00:04:20.8 & 36.44 & 51.38 & 14 & ML:2.5 & IIEES \\
\hline 67 & $2006 / 12 / 25$ & $20: 06: 54.5$ & 36.12 & 51.31 & 14 & ML:2.7 & IIEES \\
\hline 68 & $2006 / 12 / 25$ & $20: 15: 48.2$ & 36.12 & 51.32 & 14 & ML:3.1 & IIEES \\
\hline 69 & $2006 / 12 / 26$ & $15: 53: 29.9$ & 36.37 & 51.39 & 20 & ML:2.5 & IIEES \\
\hline 70 & $2007 / 06 / 04$ & 08:04:16.6 & 36.37 & 51.32 & 34 & ML:3.8 & IIEES \\
\hline 71 & $2007 / 07 / 04$ & $09: 25: 54.9$ & 36.38 & 51.33 & 15 & ML:2.5 & IIEES \\
\hline 72 & $2007 / 07 / 04$ & 09:41:22.8 & 36.31 & 51.34 & 14 & ML:2.5 & IIEES \\
\hline 73 & 2007/12/01 & 21:51:37.1 & 36.14 & 51.09 & 14 & ML:2.9 & IIEES \\
\hline 74 & 2007/12/01 & $22: 12: 45.8$ & 36.08 & 51.14 & 13 & ML:2.8 & IIEES \\
\hline 75 & 2008/10/17 & 21:01:21.9 & 36.46 & 51.01 & 18 & ML:2.9 & IIEES \\
\hline 76 & 2008/10/19 & $22: 28: 49.3$ & 36.42 & 51.01 & 15 & ML:2.8 & IIEES \\
\hline 77 & 2008/10/21 & $22: 23: 05.7$ & 36.15 & 51.23 & 12 & ML:3 & IIEES \\
\hline 78 & $2009 / 02 / 02$ & $10: 14: 10.5$ & 36.41 & 51.40 & 14 & ML:2.8 & IIEES \\
\hline 79 & 2011/08/11 & $12: 28: 35.6$ & 36.39 & 51.33 & 14 & ML:2.6 & IIEES \\
\hline 80 & $2013 / 04 / 12$ & 07:50:48.0 & 36.40 & 51.31 & 14 & ML:2.9 & IIEES \\
\hline 81 & 2013/09/12 & 03:52:30.4 & 36.44 & 51.09 & 14 & ML:2.9 & IIEES \\
\hline 82 & 2013/09/12 & $14: 56: 11.5$ & 36.44 & 51.12 & 14 & ML:3.2 & IIEES \\
\hline 83 & $2013 / 09 / 20$ & $06: 33: 26.2$ & 36.44 & 51.24 & 14 & ML:2.5 & IIEES \\
\hline 84 & $2013 / 09 / 20$ & $12: 42: 35.0$ & 36.45 & 51.17 & 14 & ML:2.9 & IIEES \\
\hline 85 & 2013/12/12 & 06:18:05.9 & 36.23 & 51.43 & 14 & ML:2.5 & IIEES \\
\hline 86 & $2014 / 08 / 29$ & 22:57:04.1 & 36.26 & 51.50 & 14 & ML:2.6 & IIEES \\
\hline
\end{tabular}


physical property of the medium within and on both sides of the fault (P). FMP is the function of these factors [1]:

$$
\mathrm{FMP}=\mathrm{f}(\sigma, \mathrm{G}, \mathrm{P})
$$

Although a geological medium is generally heterogeneous and very complicated, however it can be taken as homogeneous and isotropic in statistical view of our case. Based on this consideration, and for the purpose of simplification in the theoretical derivation, they also take the geological medium containing the faults as a homogeneous, isotropic and elastic material. Therefore fault movement potential can be simplified as:

$$
\mathrm{FMP}=\mathrm{f}(\sigma, \mathrm{G})
$$

Finally, according to [3] and [4] researches, [1] defines FMP to quantify the relationship between fault movement potential as a normalized factor by the following equations:

$$
\mathrm{FMP}= \begin{cases}0 & \theta \in\left(0^{\circ}, 30^{\circ}\right) \\ \frac{\theta-60^{\circ}}{30^{\circ}} & \theta \in\left(30^{\circ}, 60^{\circ}\right) \\ 1-\frac{\theta-60^{\circ}}{30^{\circ}} & \theta \in\left(60^{\circ}, 90^{\circ}\right)\end{cases}
$$

$\theta$ is the angle between the regional maximum principal compressive stress orientation $\left(\sigma_{1}\right)$ and the normal line of fault plane.

\subsection{Regional Tectonic Stress Orientations}

Tectonic stress means an additional stress to lithostatic stress state, in the other words, the part of stress deviated from lithostatic stress. Earthquake focal mechanism solution is one of the commonly used methods in the study of contemporary tectonic stress field. Therefore, we use results of [5]-[7] and our field study to estimate the regional maximum principal compressive stress orientation $\left(\sigma_{1}\right)$. The statistical result shows that the average attitude of $\sigma_{1}$ is $15^{\circ}, 040^{\circ}$.

This area belongs to West-Central Alborz and lesser Caucasus hinterland [8] [9] that formed on the inverted back arc intra-continental rift since Oligocene. Dominant structural trend in West-Central Alborz and lesser Caucasus province is NW-SE (Figure 1). From tectonics view, it contains deformed zone (fold and thrust belt) of Cimmerian miniplate that formed in northern active margin until late Triassic. Then it has rifted by tension in a back arc basin of Neotethyian subduction zone in the south margin of Cimmerian miniplate.

Development of that rift stopped in the late Cretaceous and then, renewed in the Eocene by spreading in submarine arc basin of Neotethyian subduction zone. In the other word, this hinterland is result of a magmatic arc system spreading in the evolutional back arc basin. After that, this region has converted to back arc regime again and West-Central Alborz and lesser Caucasus hinterland has formed by its deformation and regional uplift from SW part of Caspian Sea to Black sea. Recently, Damavand and Sebalan cones have formed by late volcanism that related to final subduction of oceanic slab (Neotethys) toward north and northeast [10]. This area has an active tectonics regime [11]-[25] in compared to the Central Iran [26]-[35] and Zagros in the southern Iran [36][43]. Also, some concepts of its metal mineralization, have been investigated by [44]-[48].

\section{Results and Discussion}

The fault movement potential of the major Quaternary faults of Marzanabad have calculated using the equations (3) and the regional stress orientation as well as the fault plane attitudes. The results are shown in Table 2 and Figure 2. Also, seismic events have $25 \mathrm{Km}$ depth as average of focal depth. The earthquakes are related to two sets of Quaternary faults with northwest-southeast and east-west strikes.

Taleqan, Kandovan, Chitan-Dozbon and Makaroud-Dalir fault zones have large angle between the normal to the fault planes and the compressive principal stress along these fault zones. The fault movement potential of this fault set ranges from medium to high, suggesting that this fault set has the sufficient potential for generating destructive earthquakes. This situation has been shown by contoured map, too (Figure 3). 
Table 2. The calculation of fault movement potential in Marzanabad in the north Alborz.

\begin{tabular}{|c|c|c|c|c|c|}
\hline Name of Fault Zone & No. & $\begin{array}{l}\text { Dominant Attitude of } \\
\text { Fault (Dip Dir.) }\end{array}$ & $\begin{array}{l}\text { Normal Line of } \\
\text { Fault Plane }\end{array}$ & $\theta$ & FMP \\
\hline \multirow{4}{*}{ Mosha-Fasham } & 01 & 017,80 & 10,197 & 39 & 0.3 \\
\hline & 02 & 022,77 & 13,202 & 33 & 0.1 \\
\hline & 03 & 025,67 & 23,205 & 41 & 0.4 \\
\hline & 04 & 009,62 & 28,189 & 52 & 0.7 \\
\hline \multirow{4}{*}{ Taleqan } & 05 & 210,58 & 32,030 & 19 & 0.0 \\
\hline & 06 & 191,50 & 40,011 & 36 & 0.2 \\
\hline & 07 & 162,39 & 51,342 & 58 & 0.9 \\
\hline & 08 & 182,35 & 55,002 & 50 & 0.7 \\
\hline \multirow{2}{*}{ Varangeh Roud } & 09 & 028,70 & 20,208 & 37 & 0.2 \\
\hline & 10 & 025,80 & 10,205 & 29 & 0.0 \\
\hline \multirow{2}{*}{ Azadkooh } & 11 & 181,77 & 13,001 & 38 & 0.2 \\
\hline & 12 & 180,78 & 10,000 & 39 & 0.3 \\
\hline \multirow{5}{*}{ Kandovan } & 13 & 002,53 & 37,182 & 63 & 0.9 \\
\hline & 14 & 027,63 & 27,207 & 44 & 0.5 \\
\hline & 15 & 024,67 & 23,204 & 41 & 0.4 \\
\hline & 16 & 004,47 & 43,184 & 67 & 0.8 \\
\hline & 17 & 019,58 & 32,199 & 51 & 0.7 \\
\hline Dona-Siahbisheh & 18 & 020,72 & 18,200 & 38 & 0.3 \\
\hline Siahbisheh & 19 & 175,60 & 30,355 & 44 & 0.5 \\
\hline Valiabad & 20 & 016,82 & 08,196 & 33 & 0.1 \\
\hline \multirow{2}{*}{ Nessen } & 21 & 009,78 & 12,189 & 41 & 0.4 \\
\hline & 22 & 004,80 & 10,184 & 44 & 0.5 \\
\hline \multirow{2}{*}{ Chitan-Dozbon } & 23 & 183,55 & 35,003 & 39 & 0.3 \\
\hline & 24 & 155,61 & 29,335 & 61 & 0.9 \\
\hline \multirow{2}{*}{ Sama-Majlar } & 25 & 358,55 & 35,178 & 64 & 0.8 \\
\hline & 26 & 008,72 & 18,188 & 46 & 0.5 \\
\hline \multirow{3}{*}{ Makaroud-Dalir } & 27 & 154,58 & 32,334 & 62 & 0.9 \\
\hline & 28 & 138,63 & 27,318 & 76 & 0.5 \\
\hline & 29 & 192,62 & 28,012 & 29 & 0.0 \\
\hline \multirow{3}{*}{ Dashte Nazir-Nater } & 30 & 197,45 & 45,017 & 36 & 0.2 \\
\hline & 31 & 131,60 & 30,311 & 82 & 0.3 \\
\hline & 32 & 166,42 & 48,346 & 55 & 0.8 \\
\hline \multirow{2}{*}{ Marzanabad } & 33 & 182,58 & 32,002 & 38 & 0.3 \\
\hline & 34 & 166,70 & 20,346 & 52 & 0.7 \\
\hline
\end{tabular}




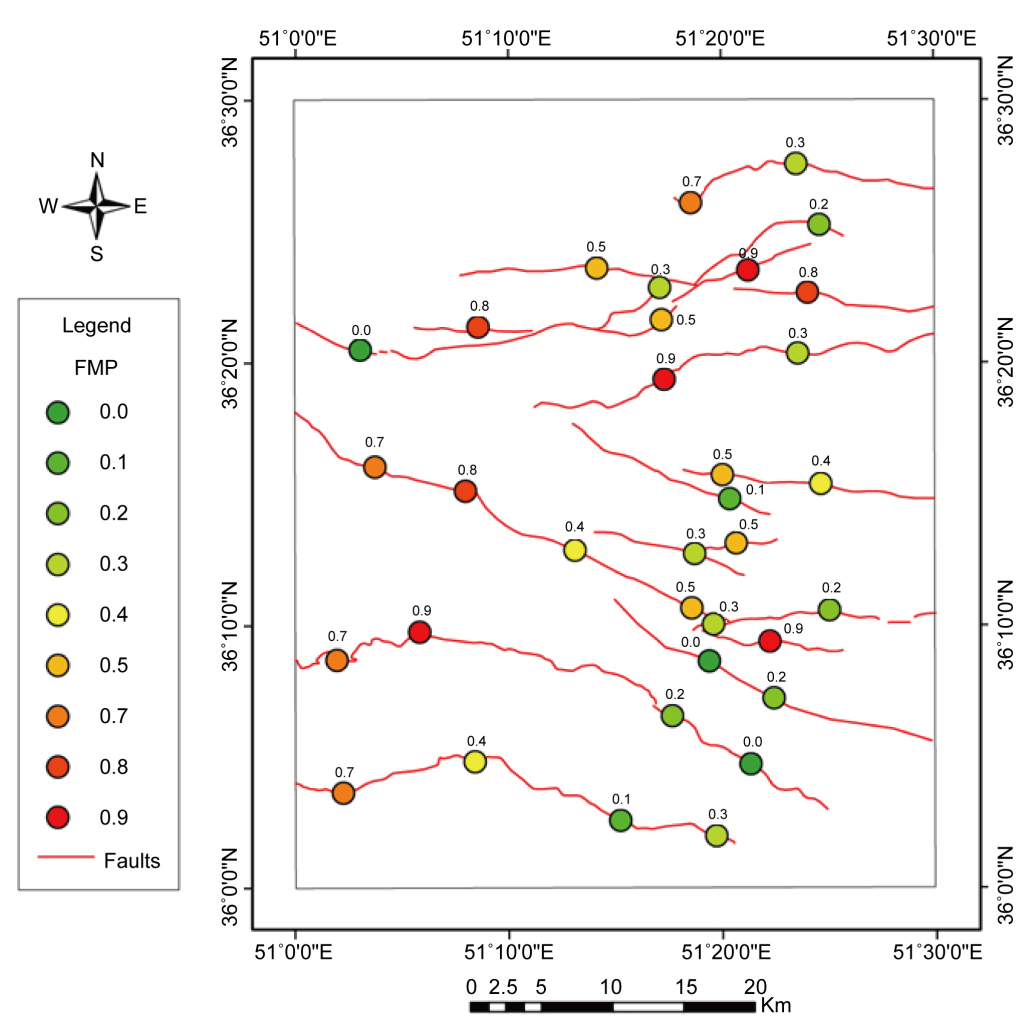

Figure 2. Stations of FMP measurements on Marzanabad area.

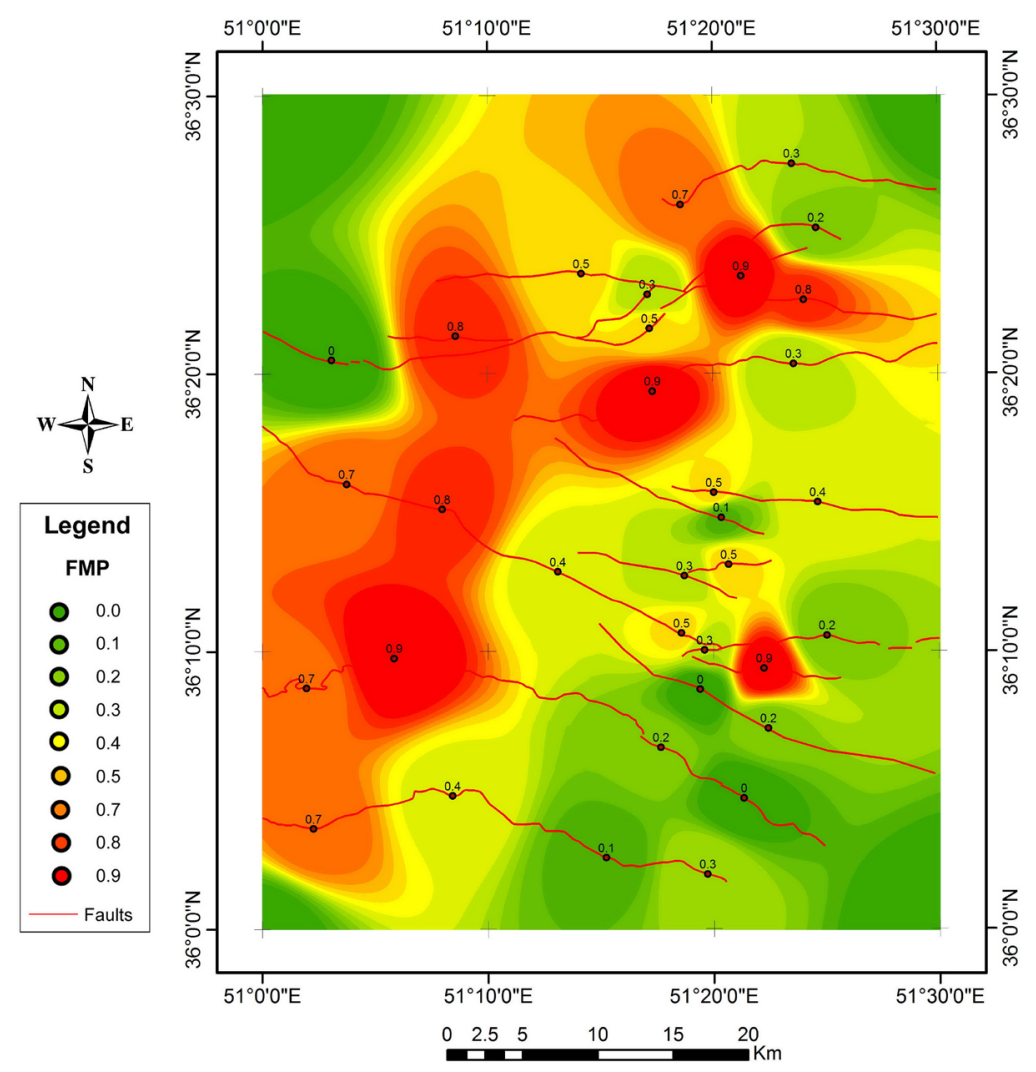

Figure 3. FMP contoured map of Marzanabad area. 


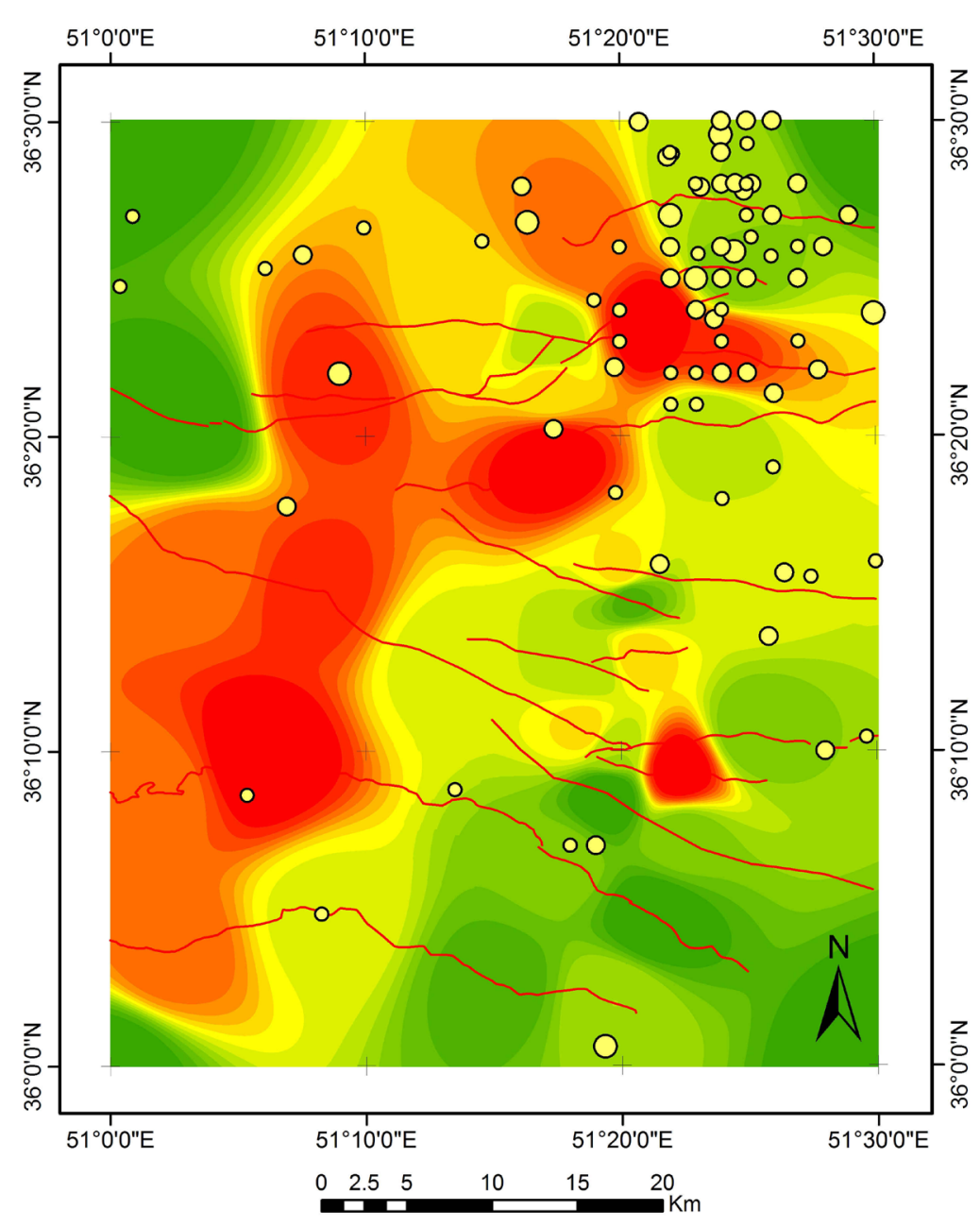

Figure 4. Epicenter of earthquakes on FMP contoured map of Marzanabad area.

In Figure 4, Epicenter of earthquakes (Table 1) on FMP contoured map of Marzanabad area have shown and it implied that high FMP values are not always coincident to previous seismic history.

\section{Conclusion}

Based on this research, the contemporary movements potential along fault zones of various orientations are different under the action of present-day regional north-northeast compressive stress field in study region. Taleqan, Kandovan, Chitan-Dozbon and Makaroud-Dalir fault zones have medium to high movement potentials. Also, the region where the fault zones have been intersected (northeastern part of study area) is prone to high seismicity; however these fault zones don't have high movement potentials.

\section{Acknowledgements}

This work has funded by the Department of geology, Islamic Azad University, Science and Research branch, Tehran, Iran. Also, Special thanks to vice-president for research in Science and Research branch, Tehran.

\section{References}

[1] Lee, C.F., Hou, J.J. and Ye, H. (1997) The Movement Potential of the Major Faults in Hong Kong Area. Episodes, 20, 227-231.

[2] Saidi, A. (2014) Shahrestanak-Marzanabad High Way Project Report. Regazaminsakht Consultant Engineering Office, Tehran. 
[3] Lokajicek, T., Spicak, A. and Waniek, L. (1988) Tectonic Stress Orientation and the Seismic Regime of a Single Fault. Tectonophysics, 152, 297-302. http://dx.doi.org/10.1016/0040-1951(88)90055-8

[4] He, S.H. (1989) The Effect of Orientation and Level of Principal Stress on Fault Movement. Crustal Deformation and Earthquake, 9, 44-52.

[5] Allen, M.B., Ghassemi, M.R., Shahrabi, M. and Qorashi, M. (2003) Accommodation of Late Cenozoic Oblique Shortening in the Alborz Range, Northern Iran. Journal of Structural Geology, 25, 659-672. http://dx.doi.org/10.1016/S0191-8141(02)00064-0

[6] Jackson, J.A., Haines, A.J. and Holt, W.E. (1995) The Accommodation of Arabia-Eurasia Plate Convergence in Iran. Journal of Geophysical Research, 100, 15205-15219. http://dx.doi.org/10.1029/95JB01294

[7] Jackson, J.A., Priestley, K., Allen, M. and Berberian, M. (2002) Active Tectonics of the South Caspian Basin. Geophysical Journal International, 148, 214-242. http://dx.doi.org/10.1046/j.1365-246X.2002.01588.x

[8] Qorashi, M. and Arian, M. (2011) Tectonics of Iran. Geologic Survey of Iran, 336 p.

[9] Arian, M. (2011) Basement Tectonics and Geology of Iran. Asar Nafis Press, 300 p.

[10] Arian, M. (2013) Physiographic-Tectonic Zoning of Iran’s Sedimentary Basins. Open Journal of Geology, 3, $169-177$.

[11] Arian, M., Maleki, Z. and Noroozpour, H. (2011) Cenozoic Diastrophism and Deformational Events in the East Central Alborz. Journal of Basic and Applied Scientific Research, 1, 2394-2400.

[12] Feizi, F., Arian, A. and Rahmani, R. (2007) Seismotectonic Zoning in the Eastern Part of the Central Alborz. Journal of Sciences, Islamic Azad University, 17, 151-164.

[13] Khavari, R., Arian, M. and Ghorashi, M. (2009) Neotectonics of the South Central Alborz Drainage Basin, in NW Tehran, N Iran. Journal of Applied Sciences, 9, 4115-4126. http://dx.doi.org/10.3923/jas.2009.4115.4126

[14] Arian, M. and Bagha, N. (2012) Active Tectonics of Tehran Area, Iran. Journal of Basic and Applied Scientific Research, 2, 3805-3819.

[15] Bagha, N., Arian, M., Ghorashi, M., Pourkermani, M., El Hamdouni, R. and Solgi, A. (2014) Evaluation of Relative Tectonic Activity in the Tehran Basin, Central Alborz, Northern Iran. Geomorphology, 213, 66-87. http://dx.doi.org/10.1016/j.geomorph.2013.12.041

[16] Arian, M. and Feizi, F. (2005) Application of Geomorphic Indices to the Assessment of Relative Tectonic Activity Levels in the Alborz-Central Iran Border Zone (from the East of Varamin to the East of Semnan). Journal of Sciences, Islamic Azad University, 15, 378-403.

[17] Arian, M. and Pourkermani, M. (2004) Tectonic Elements of South Flank in the East-Central Alborz Mountain. Journal of Sciences, Teacher Training University, 4, 359-368.

[18] Arian, M. and Qorashi, M. (2006) The Movement Potential Evaluation of the Major Quaternary Faults in Alborz-Central Iran Border Zone, from the East of Tehran to the East of Semnan. Journal of Geosciences, Geological Survey of Iran, 15, 184-188.

[19] Poroohan, N., Pour Kermani, M. and Arian, M. (2013) An Assessment of Relationship in F-Parameter and Paleostress Fields in Heterogeneous Lithologies: Roudbar Area (Northwest of Iran). Australian Journal of Basic \& Applied Sciences, 7, 933-942.

[20] Poroohan, N., Kermani, M.P. and Aryan, M. (2009) An Assessment on Correlations of Seismotectonic Parameters Preceding and Following Roudbar-Manjil Earthquake (Gilan, North of Iran). Australian Journal of Basic \& Applied Sciences, 3, 2643-2652.

[21] Pourkermani, M. and Arian, M. (2001) Structural Geomorphology of Northeastern Kurdistan, Sistan and Baluchestan University. Journal of Humanities, 7, 37-48.

[22] Mardani, Z., Ghorashi, M. and Arian, M. (2011) Geomorphic Signatures of Active Tectonics in the Talaghan Rud, Shah Rud and Sefidrud Drainage Basins in Central Alborz, Niran. Geosciences, 20, 159-166.

[23] Sorbi, A., Arian, M. and Pourkermani, M. (2011) The Application of Geomorphic Indices to the Assessment of Relative Tectonic Activity Levels in Tehran Quadrangle. Journal of the Earth, 6, 1-9.

[24] Khavari, R., Ghorashi, M., Arian, M. and Khosrotehrani, K. (2010) Geomorphic Signatures of Active Tectonics in the Karaj Drainage Basin in South Central Alborz, Niran. Geosciences Scientific Quarterly Journal, 19, 67-74.

[25] Javadi Mousavi, E. and Arian, M. (2015) Tectonic Geomorphology of Atrak River, NE Iran. Open Journal of Geology, 5, 106-114.

[26] Arian, M., Toudeshki, V.H. and Noroozpour, H. (2011) Active Tectonics of Qezel Ozan River Basin, NW Iran. Journal of Applied Environmental and Biological Sciences, 1, 291-295.

[27] Housini Toudeshki, V., Pourkermani, M., Arian, M. and Khosrotehrani, K.H. (2011) Influence of Structures on the Ghezel Ozan River. Geosciences, 21, 55-60. 
[28] Housini Toudeshki, V. and Arian, M. (2011) Morphotectonic Analysis in the Ghezel Ozan River Basin, NW Iran. Journal of Geography and Geology, 3, 258-260.

[29] Arian, M. (2012) Clustering of Diapiric Provinces in the Central Iran Basin. Carbonates and Evaporites, 27, 9-18. http://dx.doi.org/10.1007/s13146-011-0079-9

[30] Pourkermani, M. and Arian, M. (1997) Salt domes of Central Iran. Journal of Humanities University of Sistan and Balouchestan, 3, 29-41.

[31] Arian, M., Pourkermani, M., Sistanipour, A. and Noroozpour, H. (2011) Kinematic Significance of Fold- and FaultRelated Fracture Systems in the Rafsanjan's Northeast Highlands (Central Iran). Journal of Basic and Applied Scientific Research, 1, 3398-3406.

[32] Arian, M., Pourkermani, M., Sistanipour, A. and Noroozpour, H. (2011) Seismicity and Fault Segmentation of BafqBaghin Fault System (Central Iran). Journal of Applied Environmental and Biological Sciences, 1, 382-396.

[33] Asadian, F. and Arian, M. (2009) Identification of Diapiric Provinces of Central Iran through Geological and Geographical Analysis. International Journal of Agriculture Environment \& Biotechnology, 2, 3443-3451.

[34] Arian, M. (2010) Earthquake-Fault Hazard Investigations in the Kerman Quadrangle. Journal of Sciences, Islamic Azad University, 19, 176-182.

[35] Arian, M. and Noroozpour, H. (2015) The Biggest Salt-Tongue Canopy of Central Iran. Open Journal of Geology, 5, 55-60. http://dx.doi.org/10.4236/ojg.2015.52005

[36] Arian, M. and Noroozpour, H. (2015) Tectonic Geomorphology of Iran’s Salt Structures. Open Journal of Geology, 5, 61-72. http://dx.doi.org/10.4236/ojg.2015.52006

[37] Arian, M. and Aram, Z. (2014) Relative Tectonic Activity Classification in the Kermanshah Area, Western Iran. Solid Earth, 5, 1277-1291. http://dx.doi.org/10.5194/se-5-1277-2014

[38] Mashal, M., Kermani, M.P., Charchi, A., Almasian, M. and Arian, M. (2013) Pattern of Structural Geology Underground in Eastern of North Dezfol Embayment. Advances in Environmental Biology, 7, 260-268.

[39] Pazhoohan, M., Arian, M., Ghorashi, M. and Khosrotehrani, K. (2014) A Study of Drainage Pattern Responses to Active Tectonics in Tadvan Region, SW Iran. Geodynamics, 1, 36-41.

[40] Rahimi, N. and Arian, M. (2014) Tectonic Geomorphplogy of Hamedan-Sosangerd Region, West Iran. Advances in Environmental Biology, 8, 119-124.

[41] Arian, M. and Hashemi, A. (2008) Seismotectonic Zoning in the Zagros. Journal of Sciences, 18, 63-76.

[42] Arian, M., Ahmadnia, A., Qorashi, M. and Pourkermani, M. (2002) Structural Analysis of Mengharak Transcurrent Fault System in Zagros, Iran. Special Geo 2002 Conference Issue Geoarabia, 7, 209-210.

[43] Arian, M., Qorashi, M., Pourkermani, M. and Ahmadnia, A. (2006) The Structural Significance Kareh Bas Transcurrent Fault System in the Zagros Fold and Thrust Belt. Journal of Geosciences, Geological Survey of Iran, 15, 126-133.

[44] Nouri, R., Jafari, M.R., Arian, M., Feizi, F. and Afzal, P. (2013) Correlation between Cu Mineralization and Major Faults Using Multifractal Modelling in the Tarom Area (NW Iran). Geologica Carpathica, 64, 409-416.

[45] Nouri, R., Jafari, M.R., Arian, M., Feizi, F. and Afzal, P. (2013) Prospection for Copper Mineralization with Contribution of Remote Sensing, Geochemical and Mineralographical Data in Abhar 1:100,000 Sheet, NW Iran. Archives of Mining Sciences, 58, 1071-1084.

[46] Nouri, R., Afzal, P., Arian, M., Jafari, M. and Feizi, F. (2013) Reconnaissance of Copper and Gold Mineralization Using Analytical Hierarchy Process (AHP) in the Rudbar 1: 100,000 Map Sheet, Northwest Iran. Journal of Mining and Metallurgy A: Mining, 49, 9-19.

[47] Arian, M. and Nouri, R. (2015) Lineament Tectonics and Mineralizatin in Tarom Area, North Iran. Open Journal of Geology, 5, 115-124.

[48] Feizi, F. and Arian, M. (2011) The Role of Structural Controllers in Geneses of Copper Deposits in 1:50000 Map of Saiin Qaleh. Journal of Sciences, 21, 1-10. 